\section{'INSPIRE US GENIUS OF THE DAY': REWRITING THE REGENT IN THE BIRTHDAY ODE FOR QUEEN ANNE, 1703}

\author{
ESTELLE MURPHY
}

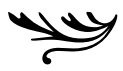

In 1701-1702 writer and poet Peter Anthony Motteux collaborated with composer John Eccles, Master of the King's Musick, in writing the ode for King William III's birthday. Eccles's autograph manuscript is listed in the British manuscript catalogue as 'Ode for the King's Birthday, 1703; in score by John Eccles' and is accompanied by a claim that the ode had already reached folio 1ov when William died, requiring the words to be amended to suit his successor, Queen Anne. A closer inspection of this manuscript reveals that much more of the ode had been completed before the king's death, and that much more than the words 'king' and 'William' was amended to suit a succeeding monarch of a different gender and nationality. The work was performed before Queen Anne on her birthday in 1703 and the words were published shortly afterwards. Discrepancies between the printed text and that in Eccles's score indicate that no fewer than three versions of the text were devised during the creative process. These versions raise issues of authority with respect to poet and composer. A careful analysis of the manuscript's paper types and rastrology reveals a collaborative process of re-engineering that was, in fact, applied to an already completed work. This article explores the problems of textual versus musical authority embodied in the ode and the difficulties faced by its creators in reworking a piece originally celebrating a foreign male war-hero for a female British queen during a period of political and religious fragility.

It has long been recognized that ceremony at court was used by the aristocracy and royalty to fashion and cultivate a public image, and the English court ode was an ideal ceremonial device with which to fashion the monarch. Its lyrics offered a positive view of the sovereign's public, political and religious policies. They were also used to show or avoid partisanship, to enhance the public perception of the monarch's power, to promote stability in periods of volatility, to reinforce the monarch's intentions for the nation and to attribute any general benevolence to his or her auspicious rule. While odes were traditionally created through court commission or in the hope of obtaining patronage, such sources of income for poets and musicians were becoming ever less important during the early eighteenth century. The expanding market for printed music and the rise of the merchant class or 'middling sort' meant that ceremonial works had a growing audience and function in the public sphere, outside of their original courtly confines. Such an afterlife further increased the importance and impact of these works, especially for their creators, who controlled dissemination for their own purposes. From this perspective, the ode is an active and formative sociopolitical device. In addition, when one takes into account its creators - their collaborative process and the creative tensions surrounding their authorial identities (especially in relation to the print market) - the ode emerges as a multifaceted and multi-authored artefact straddling the old world of patronage and the new world of the public.

This article re-examines Inspire Us Genius of the Day, with words by Peter Anthony Motteux and music by John Eccles. Written first for King William III in 1701 and then revised the following year for Queen 
Anne,the ode demonstrates how traditional ceremonial music could simultaneously serve its recipient, the monarch, and reflect the desires and ambitions of its creators. The collaborative reworking undertaken here by poet and composer exposes a rich tapestry of monarchic image-projection. Richer still are the creative tensions and authorial self-fashioning that seem to lie just beneath the surface of this reworking, and which are reflected in the ode's printed afterlife (in separate publications of several songs and the poetic text). The process of reworking Inspire Us Genius also exposes the demands of balancing music and poetry at a time of particular religious instability and political fragility in Stuart England, where the reign of Queen Anne (1702-1714) was especially important for the projection of stability, solidarity and national unity.

In 1689 the Glorious Revolution saw William and Mary crowned joint rulers of England, Scotland, France and Ireland. Their predecessor, the Catholic James II, had essentially forfeited his throne when his sonin-law, William, the Protestant Prince of Orange, set out from his native Netherlands with the intention of invading England and taking the crown. The birth of a male heir to James II spurred this invasion, as it effectively displaced Mary's position as first in line for the throne and threatened a further Catholic succession. Upon King James's departure, William III was heralded as the saviour of the Protestant faith in England. Throughout his joint reign with Queen Mary, he continued to strive, as he had before, to spread Protestantism on the Continent and limit the Catholic influence of France and Spain. This reign was fraught with instability, being under constant threat from the displaced James II and his Jacobite supporters. Frequent uprisings - the most famous of which is the Battle of the Boyne of 1690 - were a constant threat to the king's position. Not surprisingly, therefore, the projection of William III as a hero in the eyes of his subjects is very evident in the texts of the musical odes performed annually for celebrations of the New Year and the monarchs' birthdays. Such projections are easily discernable in lines such as these from the birthday ode for William III in 1690, Matthew Prior's As through Britannia's Raging Sea:

Awake the Trumpets, rouze the Drums,

The King, the Conqueror, the Hero comes,

With shining Arms he decks the listed Fields,

IO Britannia! Then JERNE yields,

IO Britannia! Bless the Conqueror,

Put all thy Glory on, exert thy Power

And greet thy WILLIAM's happy Toil... ${ }^{1}$

Queen Mary died in December 1694, leaving just two occasions on which odes were required: the New Year and the king's birthday (which fell on 4 November Old Style and 14 November New Style). However, both Princess Anne and her son, Prince William Henry, had odes written for them by various composers during their time as heirs presumptive and apparent. ${ }^{2}$ During this period, responsibility for the production of odes had yet to be fixed. Typically, a prominent poet would write the text and a similarly distinguished composer, usually in the employ of the court, would set this text to music. From 1693 it was typical for the Poet Laureate and the Master of the King's Musick to be given these tasks, but it was only during the reign of Queen Anne that this became firmly established. ${ }^{3}$

1 Matthew Prior, A | Pindarique | on | His Majesties Birth-Day. I By Mr. Prior I Sung before Their Majesties at Whitehall, I The Fourth of November 169o. I A Prophecy by Apollo (composer unknown). GB-Lbl, Ashley 4955. There is emphasis here and throughout this ode on King William's most recent victory in Ireland ('JERNE') at the Battle of the Boyne.

2 Prince William Henry was heir presumptive (meaning that his position could be displaced by the birth of an heir to the reigning monarchs) until Queen Mary's death in 1694 . He then became heir apparent. His mother was effectively heir apparent to the heir apparent until William Henry's death in 1700 , when she became the sole heir apparent.

3 Nahum Tate held the position of Poet Laureate from 1692 until his death in 1715. Though he did not provide poetry for all of the odes written for Queen Anne in this period, he did so frequently from the middle of her reign. For a detailed discussion of the Poet Laureate's duties see Estelle Murphy, 'The Fashioning of a Nation: The Court Ode in the Late Stuart Period' (PhD dissertation, University College Cork, 2012), volume 1, chapter 2. 
William III died unexpectedly on 8 March 1702 from pneumonia, a complication brought on by a broken collarbone he received after falling from his horse. His death threw the line of royal succession into a state of precariousness, for Anne's numerous miscarriages and stillbirths, together with the deaths of two infant daughters in 1687 and of the eleven-year-old Prince William Henry in 170o, had left the country without an heir. This resulted in the Act of Settlement of 1702, which ensured that the line of succession would remain Protestant. The assurance of stability that came with Queen Anne's succession to the throne was therefore of utmost importance. As has been observed by many of her biographers, Anne's near obsession with ceremony led (in the early years of her reign, at least) to the revival of various courtly rituals and traditions. ${ }^{4}$ As a result, the court ode flourished at this time and became an essential part of public ceremony. The first ode composed for the queen, therefore, was of great ceremonial significance, and makes the unusual history of its composition even more crucial to our understanding of musical creativity and the public self in this period.

Inspire Us Genius was first performed for Queen Anne's birthday on 6 February (Old Style) 1703. The noteworthy poet Peter Anthony Motteux, a Huguenot royalist, provided the text and John Eccles, Master of the King's Musick, set it to music. It is likely that Motteux's established working relationship with Eccles led to his being chosen for the task; they had collaborated previously on various works for the theatre, including Haste, Loyal Britons, Haste, Prepare, to celebrate the taking of Namur and the king's safe return (1696), Love's a Jest (1696), Europe's Revels for the Peace, and his Majesty's Happy Return (1697) and The Deceiver Deceived (1698), as well as on the birthday ode for William III in 1700 (lost). Inspire Us Genius was the second ode on which Eccles and Motteux collaborated following the composer's appointment as Master in 1700.

The ode is scored for four soloists (two countertenors, tenor and bass), SATB chorus, strings, oboe and continuo. ${ }^{6}$ The gentlemen of the Chapel Royal typically performed ode choruses, with soloists drawn from its ranks as well as from the theatres. In the case of Inspire Us Genius, solo singers are named in Eccles's score and in some titles of the songs printed later. The singers named present something of a puzzle: at the opening of the trio 'Inspire us genius of the day', Eccles has curiously amended the bass singer's name from 'Cook' to 'Williams' (see Figure 1). This was either for the ode's second performance at Little Lincoln's Inn Theatre on 11 February 1703,7 or because the bass part was reassigned after the music had gone to press. The former scenario is more likely, for further on in the manuscript the bass voice part is labelled with the name 'Cook' for 'From this happy day'. Moreover, the titles of the songs in the editions printed shortly afterwards tell us that it was Cook who sang 'Inspire us genius', 'From this happy day' and 'Firm as a rock' before the queen on her birthday in $1703 .{ }^{8}$ Cook (or Cooke) was a singer (and possibly a violinist) active on the London stage during the years 1694-1718. In the early years of the eighteenth century he appeared frequently at Lincoln's Inn Fields, and was listed in several billings for performances at the Queen's Theatre. He seems to have been involved in a number of productions for which Eccles provided music, including Macbeth (1694), The Mad

4 See, for example, James A. Winn's recent biography, Queen Anne: Patroness of Arts (Oxford: Oxford University Press, 2014), and Robert O. Bucholz, The Augustan Court: Queen Anne and the Decline of Court Culture (Stanford: Stanford University Press, 1993).

5 Poet Laureate Nahum Tate was not, at this time, obliged to supply poetry for the odes.

6 An obbligato oboe is required for the solo song for bass voice 'Firm as a Rock', though it is likely that oboes also doubled the strings in other movements.

7 The Post Man, 9-11 February 1703, cited in Judith Milhous and Robert D. Hume, The London Stage 1660-180o (revised edition), Part 2, 1700-1729 <www.personal.psu.edu/users/h/b/hb1/London\%2oStage\%202001/lond1702.pdf> (30 January 2015).

8 GB-Lcm, D40, f. 3: The I Songs I and Symphonys I Perform'd before Her I Majesty at her Palace I of St. Jame's on her Birth Day. 1703 I Composed by Mr Eccles I Master of Her Majestys I Musick (London: Walsh[, 1703]); GB-Ob, Don. C. 56, f. 17: Mr I Ino. Eccles I General Collection I of SONGS (London: Walsh[, 1704]). The title appeared only in the 1704 edition. 


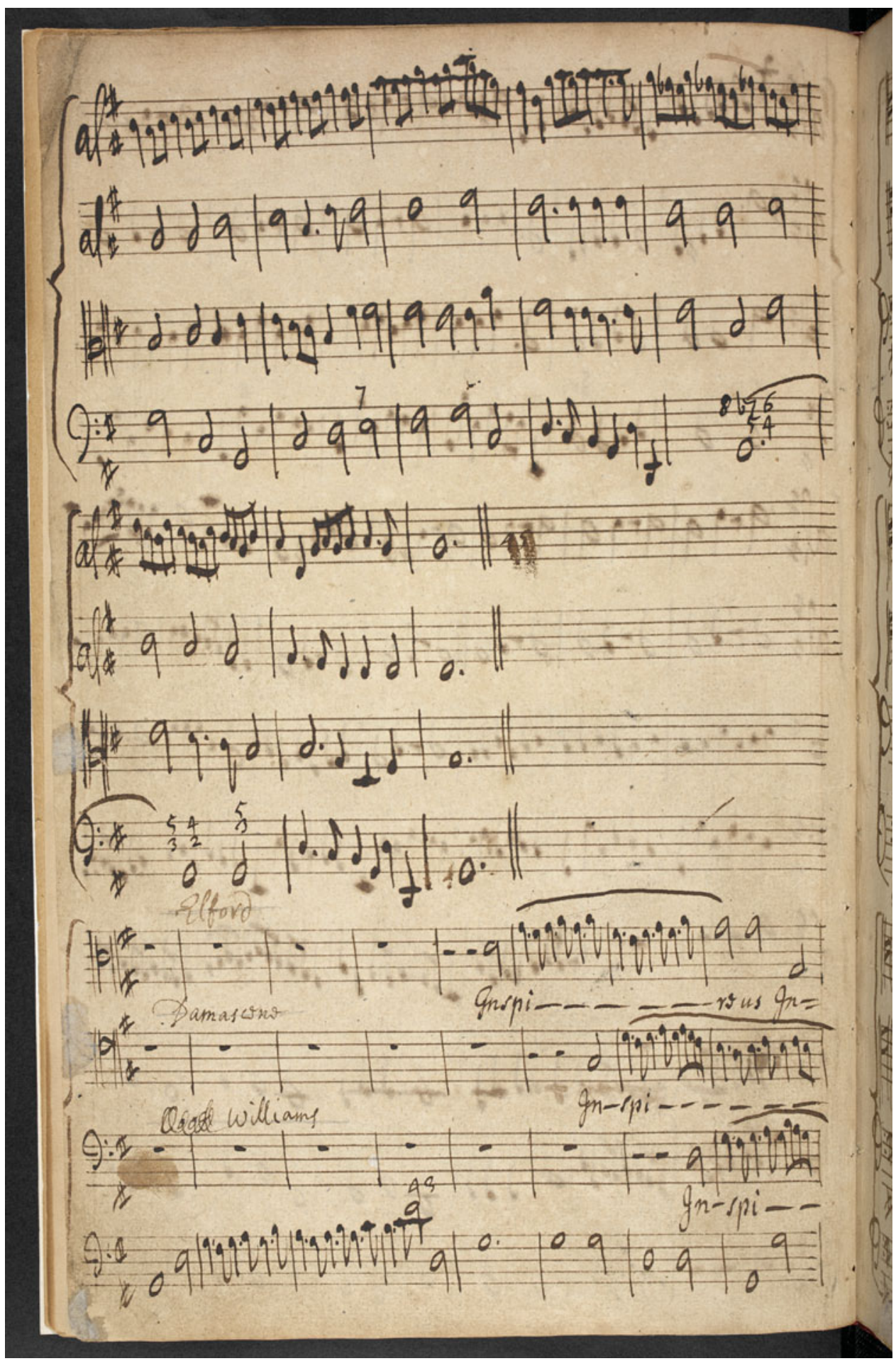

Figure 1 (Colour online) John Eccles, Inspire Us Genius of the Day, opening of trio 'Inspire us genius of the day', with Cook's name scratched out and replaced by Williams. GB-Lbl, Add. 31456, f. 2v. Used by permission 
Lover (1700), The Biter (1704) and The Island Princess (in January 1715), to name but a few. ${ }^{9}$ The other bass singer was most probably Daniel Williams (c1668-1720), a gentleman of the Chapel Royal and Clerk of the Cheque. ${ }^{10}$

The other singers named in the manuscript (Elford, Robert and Damascene) were all drawn from the ranks of the Chapel Royal and the Queen's Musick. Richard Elford, a well-known countertenor, seems to have been a favourite of Anne's, given that he was admitted as a lay clerk at St George's Chapel, Windsor in December 1701, 'having been recommended by the Princess [Anne]', and later in 1702 was sworn in as a gentleman in the Chapel Royal 'in an additional place to be added to the establishment." ${ }^{11}$ Though he was described as a countertenor by both Burney and Hawkins, many composers, including Handel, Clarke, Blow, Weldon, Croft and Eccles, wrote for him in the high tenor range (as Eccles does in Inspire Us Genius). ${ }^{12}$ Robert was most likely Anthony Robert, a tenor in the Private Musick who sang in a number of other birthday odes, including Purcell's Sound the Trumpet, Beat the Drum for James II's 1687 celebration, Arise My Muse and Celebrate This Festival for Queen Mary in 1690 and 1693, and Who Can from Joy Refrain? for the young Duke of Gloucester in $1695 .{ }^{13}$ Alexander Damascene, a countertenor and composer whose name appears in lists of the Private Musick from 1689 and as an extraordinary gentleman of the Chapel Royal from December 1690 (made ordinary upon the death of Purcell in 1695), was similarly involved in other ode performances. He sang alongside Robert in Purcell's Arise My Muse, Celebrate This Festival and Who Can from Joy Refrain? and also performed in Come ye Sons of Art for Queen Mary's birthday in 1694 and in the 1692 Cecilian ode Hail, Bright Cecilia. ${ }^{14}$

Among court odes from the early eighteenth century, Inspire Us Genius is of particular musical merit, being the most impressive of Eccles's extant odes. Stoddard Lincoln remarks that it 'is a magnificent piece, filled with careful work and great exuberance', and though Rosamond McGuinness is critical of Eccles's odes, describing them generally as 'by far the worst of his output', she is careful to point out that this observation is 'with the exception of the 1703 ode and a movement or two from other odes. ${ }^{15}$ Here the contrapuntal writing characteristic of the Chapel Royal tradition, and found in earlier odes by Blow and Purcell, gives way to a more theatrical (though perhaps less refined) idiom. Indeed, Eccles's experience as a theatre composer is to the fore in Inspire Us Genius, with the songs shining through as self-contained pieces in their own right. They range from the florid trio 'Inspire us genius' to the dramatic virtuosity of 'Blest day' (see Figure 2). Perhaps the most impressive movement is the trio; originally sung by Elford, Damascene and Cook, it is a movement of beauty and elegance that seems to have attained some degree of renown; it was published not only in Eccles's The Songs and Symphonys Perform'd before Her Majesty at her Palace of St. Jame's on her Birth Day. 1703 and in his General Collection of Songs of 1704, but also appears in three eighteenth-century manuscripts,

9 'Cook, Mr [fl. 1694-1718], singer, violinist?' in Philip H. Highfill, Jr, Kalman A. Burnim and Edward A. Langhans, A Biographical Dictionary of Actors, Actresses, Musicians, Dancers, Managers and Other Stage Personnel in London, 1660-180o, volume 3: Cabanel to Cory (Carbondale: Southern Illinois University Press, 1975), 442-443.

10 Andrew Ashbee and David Lasocki, assisted by Peter Holman and Fiona Kisby, A Biographical Dictionary of English Court Musicians, 1485-1714, volume 2 (Aldershot: Ashgate, 1998), 1153-1154; Philip H. Highfill, Jr, Kalman A. Burnim and Edward A. Langhans, A Biographical Dictionary of Actors, Actresses, Musicians, Dancers, Managers and Other Stage Personnel in London, 1660-180o, volume 16: W. West to Zwingman (Carbondale and Edwardsville: Southern Illinois University Press, 1993), 137-138.

11 Ashbee and others, Biographical Dictionary of English Court Musicians, volume 1, 384-386.

12 Olive Baldwin and Thelma Wilson, 'Elford, Richard', Grove Music Online < www.oxfordmusiconline.com> (30 January 2015).

13 Ashbee and others, A Biographical Dictionary of English Court Musicians, volume 2, 964-965.

14 Ashbee and others, A Biographical Dictionary of English Court Musicians, volume 1, 333-334.

15 Stoddard Lincoln, 'John Eccles: The Last of a Tradition' (PhD dissertation, University of Oxford, 1963), 390. Rosamond McGuinness, English Court Odes, 1660-1820 (Oxford: Clarendon, 1971), 142. 


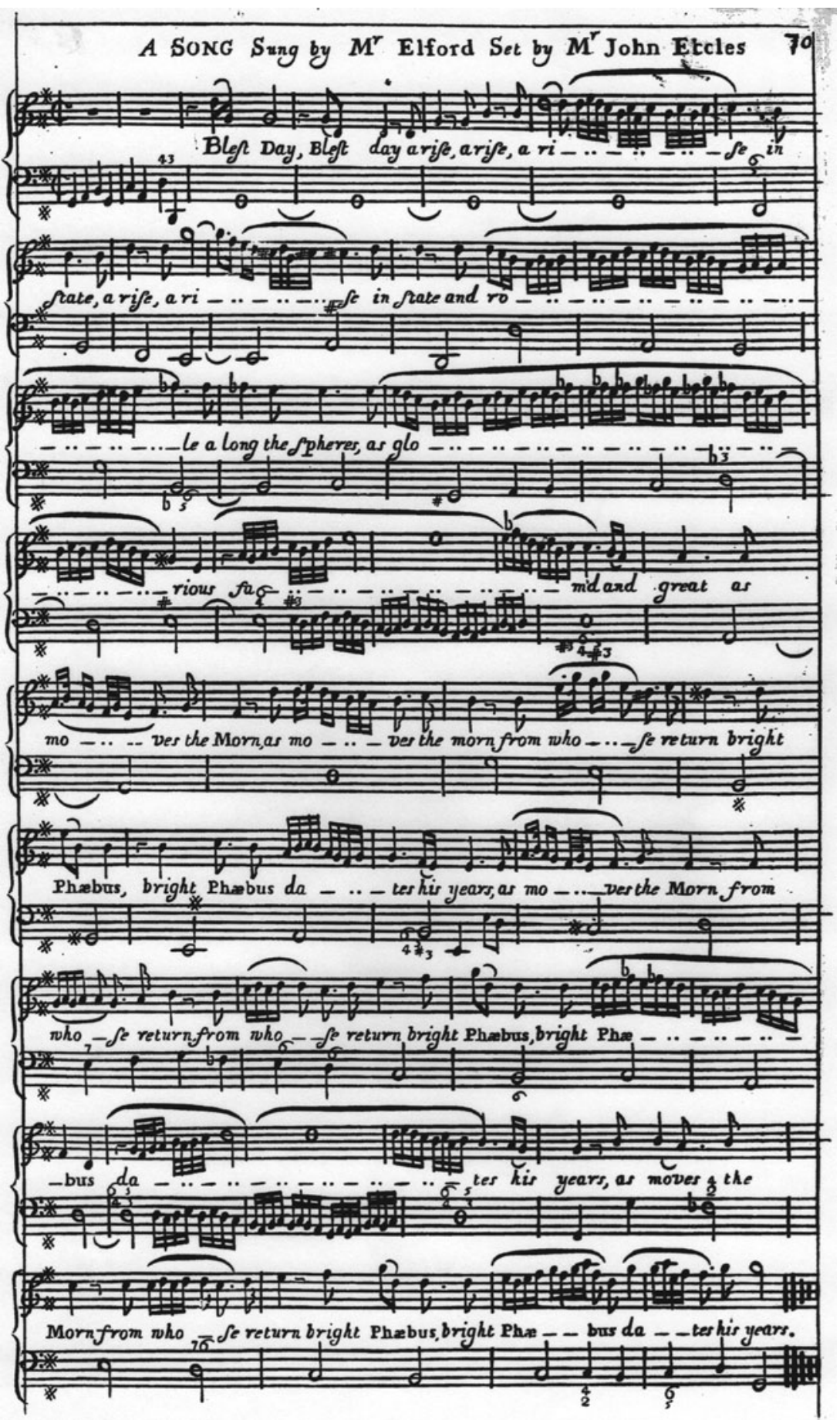

Figure 2 Eccles, Inspire Us Genius of the Day, 'Blest day', as it appears in The songs and Symphonies Perform'd before Her MAJESTy at her palace of St Jame's on her birthday. 1703 Composed by Mr: ECCLEs Master of Her MAJEstys Musick (London: Walsh[, 1703]). GB-Lcm, D40. Used by permission 
apparently copied from these publications. ${ }^{16}$ The choruses in Inspire Us Genius are modern and homophonic and build on the material of their preceding songs. They include some interesting diatonic harmonizations, and there is even use of minor-key chromatic progressions in 'By seasons and by fleeting hours'.

\section{RASTROLOGY AND REVISION}

In order to establish how much of the ode had been completed by the time of King William's death, it is necessary to examine the autograph manuscript from a codicological perspective. The following discussion of the rastrology, paper types and textual amendments demonstrates which parts of the ode were revised or newly composed for Queen Anne, allowing the work's genesis to be understood fully for the first time. Such analysis is also integral to understanding the collaborative effort between poet and composer.

The manuscript comprises twenty-nine folios in upright format, with twelve staves ruled on each page. The binding is tight and it is, unfortunately, impossible to tell from examination of the gutter whether these are single sheets or bifolios. There is no title page, but f. $29 \mathrm{v}$ bears Eccles's name, which has blotted onto the single, unruled folio that follows (presumably a wrapper). The handwriting is consistent throughout the ode, and there can be no doubt but that this manuscript is autograph when one compares it with other known examples of Eccles's writing, such as his music for Macbeth of 1694 (GB-Lbl, Add. 12219) and his 1701 Ode for St Cecilia's Day, Oh Harmony, to Thee We Sing (GB-Lbl, RM.24.d.6). This is especially clear from a comparison of treble clefs (a thin, swirling ' $G$ ', as can be seen in Figures 1, 3, 6 and 7 ) and time signatures in all three manuscripts. Also strikingly similar is the underlaid text and formation of semiquavers and other note shapes. The manuscript of Inspire Us Genius appears at first glance to be a 'fayre' score, copied from the composer's 'fowle originalls.' ${ }^{17}$ There is evidence that it was intended to be used as an exemplar from which copyists were to draw individual performance parts: at bar 21 of the Overture on f. 1 , and at bar 45 of the second movement on f. 4 r, Eccles has written in the total number of bars to these points. To my knowledge, little research has been undertaken in regard to the presence and function of tally numbers in English manuscripts. ${ }^{18}$ Scholarship dealing with the autograph manuscripts of Antonio Vivaldi, to take a nearly contemporaneous example, reveals that the composer commonly used tally numbers, particularly when the manuscript in question was intended as an exemplar from which to make copies. ${ }^{19}$ Despite significant changes made to the Inspire Us Genius manuscript during the process of reworking, it can be considered a

16 The manuscripts include GB-Lcm, MS 1064, fols 28v-29; GB-Lbl, Add. 31808, fols 97-99v; and GB-Lbl, Add. MS 31806, fols 52-54. Further testifying to this movement's longevity and popularity is a printed concert programme from 'Harrison and Knyvett's Vocal Concert' dating from 1793. Described as a 'GLEE, 3 Voices and CHORUS. Eccles', the programme reproduces the lyrics of the trio and the chorus that follows.

17 For discussion of terminology recently established in relation to eighteenth-century manuscripts such as this, see Rebecca Herissone, “Fowle Originalls” and "Fayre Writeing”: Reconsidering Purcell's Compositional Process', The Journal of Musicology 23/4 (2006), 586.

18 Rebecca Herissone notes the presence of tally marks in a non-autograph manuscript of Purcell's keyboard music and settings (US-Lauc M678). However, she asserts that their presence together with fingerings suggests that the manuscript was used for teaching. Herissone, Musical Creativity in Restoration England (Cambridge: Cambridge University Press, 2014), 111 and Appendix: Musical Creativity in Restoration England <http://documents.manchester. ac.uk/display.aspx?DocID $=16614>$ (30 January, 2015).

19 Michael Talbot hypothesizes that a group of Vivaldi's autograph manuscripts of sacred works written in Venice were intended for use as exemplars elsewhere in Italy, quite possibly for the liturgy of St Laurence Martyr. Michael Talbot, The Sacred Vocal Music of Antonio Vivaldi (Florence: Olschki, 1995), 167-168. Many thanks to Paul Everett for bringing Talbot's discussion to my attention. Everett suggests that the presence of tally numbers (among other features) in Vivaldi's Dixit Dominus RV594 indicates that 'he designed the score as a definitive text from which performance materials were to be derived'. Antonio Vivaldi, Dixit Dominus Salmo in due cori RV 594, ed. Paul Everett (Milan: Ricordi, 2002), 156. 


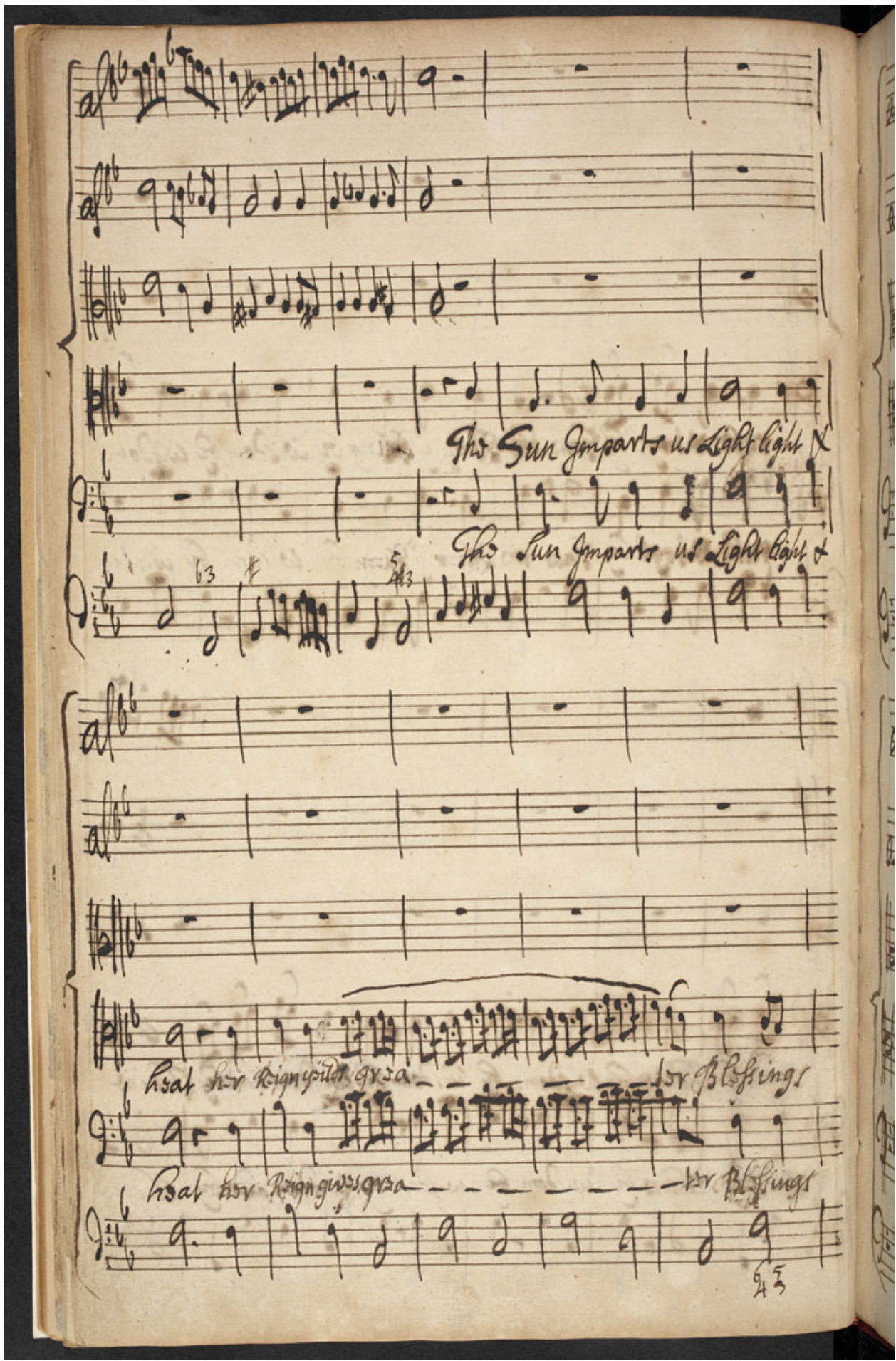

Figure 3 (Colour online) Music Paper A, ruled with two sets of six staves. Emendations made to the line 'her Reign yields/gives greater Blessings', visible in text under staves 10 and 11. GB-Lbl, Add. 31456, f. 10v. Used by permission 


\begin{tabular}{|c|c|c|c|}
\hline Type & Ruling & Distinctive features & $\begin{array}{l}\text { Textual/musical } \\
\text { amendments }\end{array}$ \\
\hline \multirow[t]{2}{*}{ Music Paper A } & $\begin{array}{l}\text { Twelve staves ruled with a } \\
\text { six-stave rastrum, span: } \\
128.5 \mathrm{~mm}\end{array}$ & $\begin{array}{l}\text { Stave } 1 \text { top space ( } \mathrm{e}^{2} \text { in treble clef) } \\
\text { narrow: } 2.75 \mathrm{~mm}\end{array}$ & Yes \\
\hline & & $\begin{array}{l}\text { Stave } 2 \text { first space ( } \mathrm{f}^{1} \text { in treble clef) } \\
\text { wide: } 3.45 \mathrm{~mm} \\
\text { Space between staves } 4 \text { and } 5 \text { notably } \\
\text { large }\end{array}$ & \\
\hline Music Paper B & $\begin{array}{l}\text { Twelve staves ruled with a } \\
\text { six-stave rastrum, span: } \\
128 \mathrm{~mm}\end{array}$ & $\begin{array}{l}\text { Span of top stave notably wider than } \\
\text { that of Music Paper A: } 1.275 \mathrm{~cm}\end{array}$ & No \\
\hline Music Paper C & $\begin{array}{l}\text { Twelve staves ruled with a } \\
\text { four-stave rastrum, span: } \\
105.7 \mathrm{~mm}\end{array}$ & $\begin{array}{l}\text { First space notably larger in bottom } \\
\text { stave of each set of four (staves } 4,8 \\
\text { and } 12 \text { counting from top) }\end{array}$ & No \\
\hline
\end{tabular}

fair copy in the hand of the composer and was most probably intended as an exemplar to be drawn into parts by copyists. ${ }^{20}$

According to the British Library catalogue, the composition of the ode had reached f. 1ov when the king died unexpectedly:

ODE for the King's birthday, 1703; in score, by J. Ecsles [sic] King William died when the composition had reached f. 1ob, and the words up to that point have been amended to suit his successor. The names of the original singers appear in their places. Autograph; signed at the end. Paper; ff. 29. Folio. ${ }^{21}$

However, as we shall see, much more of the ode had been completed before the king's death and much more than the words 'king' and 'William' was amended to suit a succeeding monarch of a different gender and nationality. It is only in the ode's last two movements (from f. 18r) that the text deals with the topic of a female monarch. On the surface, the remaining text appears to be non-gender-specific and to work equally well for either William or Anne.

Three distinct batches of twelve-stave music paper, as defined by their rastrologies, are identifiable in the manuscript. Their dispersal throughout the work, analysed in tandem with watermarks and evidence of textual emendation, holds the key to unlocking the revision process undertaken by poet and composer. As illustrated in Table 1, two of these types of paper (A and B) have pages ruled in two sets of six staves, whereas the third type $(C)$ is ruled in three sets of four staves. ${ }^{22}$ Table 2 shows that type A is found most frequently in the manuscript, and it is on these folios that all textual changes were made. Therefore, type A represents the original batch of paper, used when the ode was designed for William III. Types B and C are found in insertion and/or replacement pages added to the manuscript after the king's death. The nine watermarks in the main body of the manuscript align with these three paper types (see Tables 2 and 3 ),

20 Herissone discusses similar revisions made to file copies, including Henry Purcell's practice of adding slips of paper to cover an original, rejected passage. See Herissone, "Fowle Originalls" and "Fayre Writeing”, 590-591, and 'Purcell's Revisions of His Own Works' in Purcell Studies, ed. Curtis Price (Cambridge: Cambridge University Press, 1995), 58-62. 21 The British Library Archive and Manuscripts Catalogue Online, <http://searcharchives.bl.uk/primo_library/libweb/ action/search.do?vid=IAMS_VU2> (30 January, 2015).

22 'Paper type' here and below refers to the identification of paper according to rastrology. 
Table 2 Distribution of paper types and watermarks in GB-Lbl, Add. 31456

\begin{tabular}{|c|c|c|c|}
\hline Paper type & Folio & Movement/incipit & Watermark \\
\hline \multirow[t]{2}{*}{ A } & 1 & 1. Overture & 1 \\
\hline & 2 & 2. Inspire us & 2 \\
\hline \multirow[t]{4}{*}{$\mathrm{B}^{*}$} & 3 & & $3^{*}$ \\
\hline & 4 & 2a. [Chorus] Joyn all ye Muses & 4 \\
\hline & 5 & & 2 \\
\hline & 6 & & $4 ?$ \\
\hline \multirow{4}{*}{ A } & 7 & 3. Blest day arise in state & 4 \\
\hline & 8 & 4. From this happy day & 2 \\
\hline & 9 & & 5 \\
\hline & 10 & & 4 \\
\hline $\mathrm{B}$ & 11 & & 6 \\
\hline \multirow[t]{2}{*}{ A } & 12 & & 2 \\
\hline & 13 & 4a. [Chorus] By seasons and by fleeting hours & 7 \\
\hline \multirow[t]{2}{*}{$\mathrm{C}$} & 14 & & 5 \\
\hline & 15 & 5. No, Albion, thou can'st ne'er repay & 7 \\
\hline \multirow[t]{2}{*}{ A } & 16 & & none \\
\hline & 17 & & 2 \\
\hline $\mathrm{C}$ & 18 & 6. Firm as a rock & 5 \\
\hline \multirow[t]{2}{*}{ B } & 19 & & 8 \\
\hline & 20 & & 6 \\
\hline \multirow[t]{3}{*}{$\mathrm{C}$} & 21 & & 7 \\
\hline & 22 & 7. Great Queen go on & 8 \\
\hline & 23 & & 8 \\
\hline \multirow[t]{4}{*}{ B } & 24 & & 8 \\
\hline & 25 & & none \\
\hline & 26 & & 8 \\
\hline & 27 & & 4 \\
\hline \multirow[t]{2}{*}{ A } & 28 & & 4 \\
\hline & 29 & & 2 \\
\hline
\end{tabular}

confirming that the manuscript was assembled in two distinct stages. Folios with watermarks depicting a lion and unicorn (watermarks 2, 3, 7 and 8) are Dutch in origin and were sold extensively on the London market. ${ }^{23}$ The final folio of the manuscript, which is not ruled with staves and was presumably added as a wrapper some time after the completion of the manuscript, bears the watermark of a shield. As might be expected, this watermark does not match others in the rest of the manuscript.

In instances where the underlaid text has been changed, examinations of rastrology and watermarks lead to some surprising conclusions. The original version of the text for Inspire Us Genius of the Day as it was written for William III does not appear to survive in any medium. Only part of this original version, labelled 'Version A' in Table 4, can be recovered from the altered text for Queen Anne ('Version B') in Eccles's manuscript. A hitherto unidentified third version of the poem, surviving in print without the music, is held

23 See W. A. Churchill, Watermarks in Paper in Holland, England, France, etc., in the XVII and XVIII Centuries and their Interconnection (Amsterdam: Hertzberger, 1967), 46. Similar watermarks showing the Arms of Amsterdam are illustrated on pages cxcii and iii-xlviii. Note that f. 3 , indicated as music paper B* in Table 2 , appears to be a rogue folio. Though its ruling bears a strong resemblance to Type B folios, its watermark is unique in the manuscript. Hence it is likely, given its textual content, that it was used in tandem with music paper A when the work was originally completed for William III. 
Table 3 Description of watermarks in GB-Lbl, Add. 31456

\begin{tabular}{lll}
\hline Watermark & Description & Folios \\
\hline 1 & Large 'D' or top half of a 'B' & 1 \\
2 & Ornate circle containing a lion & $2,5,8,17,29$ \\
3 & Lion and unicorn straddling a crown on a pole decorated with 'XXX' & 3 \\
4 & Small 'HD' in cursive with thin lines & $4,6 ?, 7,10,12,27,28$ \\
5 & 'CB' in block capitals & $9,14,18$ \\
6 & 'DI' or 'DT' in block capitals & 11,20 \\
7 & Lion and unicorn straddling a crown on a pole (variation of watermark 3) & $13,15,21$ \\
8 & Lion and unicorn straddling a large crown & $19,22,23,24,26$ \\
9 & Shield, lighter paper than the rest of the manuscript (used as a cover) & 30 \\
\hline
\end{tabular}

at Lambeth Palace Library ('Version C'). ${ }^{24}$ The first instance of any changes to the text occurs on f. 9r. This is the third page of 'From this happy day' (fols 8-15; music paper A), the fourth and largest movement in the ode, beginning with three voices punctuated by string accompaniment and ending with a chorus. The movement contains the first appearance of Anne's name in the ode; preceding movements use neither the monarch's name nor the word 'queen'. The original opening lines of 'From this happy day', visible when the manuscript is viewed under ultraviolet light, read as follows:

From this happy, happy day we date,

William's birth and Europe's joys.

Planets rule and toil by fate,

The King by wisdom and by choice.

Not only the words 'William' and 'king' were altered in the reworking of this movement, but also the word 'Europe'. The amended text reads as:

From this happy, happy day we date,

Anna's birth and Britain's joys.

Planets rule and toil by fate,

The Queen by wisdom and by choice.

Similar changes were made to the text on $\mathrm{f}$. 10v, where the tenor sings 'Her reign yields greater blessings' simultaneously with the bass's line 'Her reign gives greater blessings' (my italics). As the repetition of the line on f. 11r uses 'gives', it is clear that Eccles neglected to correct 'yields' in the tenor part on f. 1ov (Figure 3 ). In fact, the only word in the line that appears not to have changed is 'greater'; under ultraviolet light, it is evident that 'Her Reign' was originally 'Our Hero'.

Though most of 'From this happy day' is written on type A paper, f. 11 is on type B. This single folio includes no textual alterations, indicating that it is a freshly written insertion. Presumably the original folio, which must have been on type A paper, was damaged or made unusable owing to textual changes. Indeed, the alterations to the preceding page, f. 10v, caused a hole in the paper where the ink had to be scratched away. The final three folios of the movment (fols 13-15) are on type $\mathrm{C}$ paper. This would appear to be an insignificant discrepancy but for the fact that the next movement, 'No, Albion, thou can'st ne'er repay', begins on the reverse of the final folio (f. 15v) and includes similar textual emendments. On f. 16v 'Anna[']s' is written in pencil above the vocal line as a reminder to change the text, showing that the alterations were a well-planned exercise (Figure 4, third system). Under ultraviolet light, it is clear that 'Anna' and 'Anna's'

24 GB-Llp, ${ }^{* *}$ SR1175 1.033. It should be noted that the published songs from the ode contain poetry matching that of the manuscript (and not the printed poem), but for insignificant spelling discrepancies. 
Table 4 Three versions of the text to Inspire Us Genius of the Day

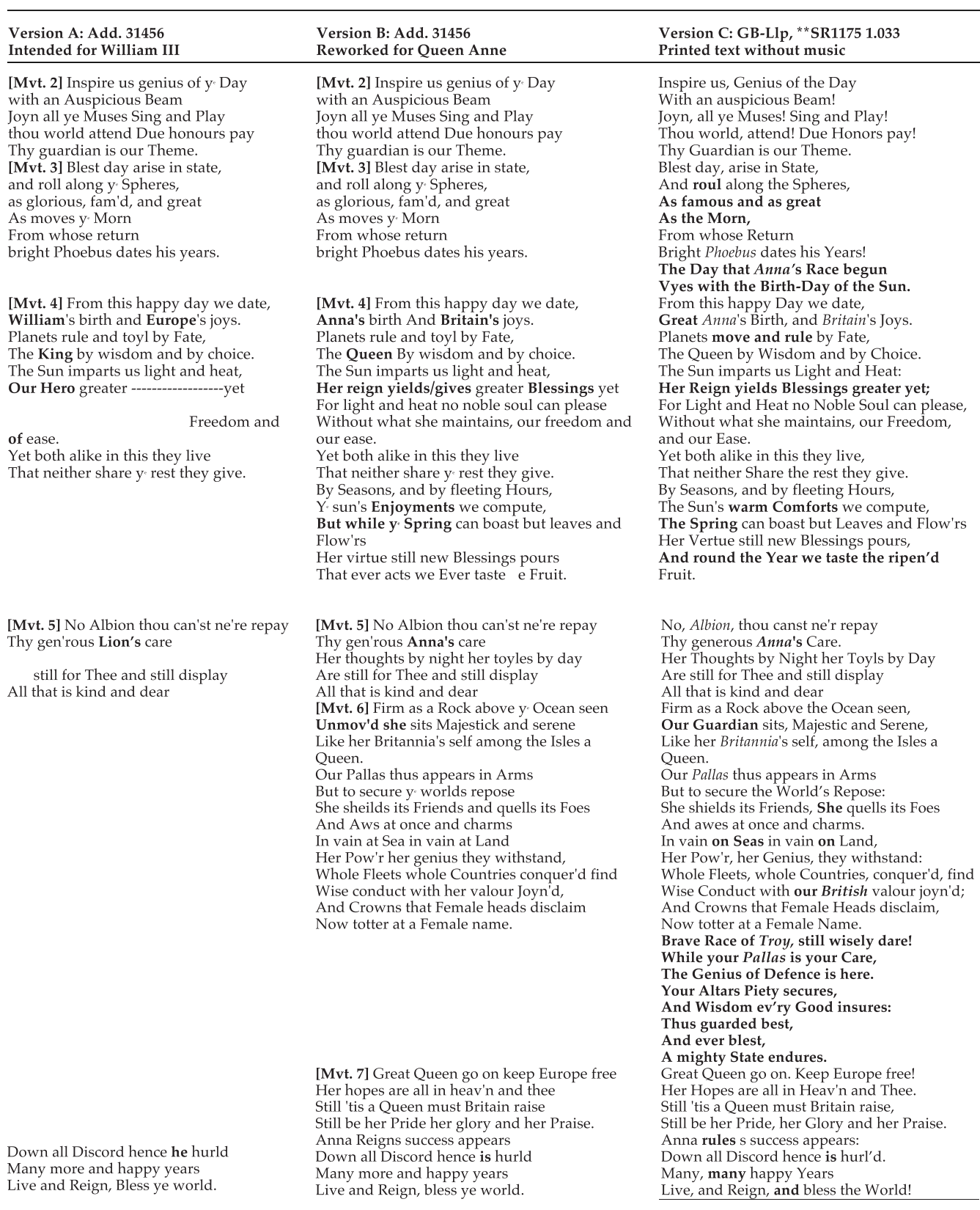

were originally 'Lion' and 'Lion's'. As expected, this amendment does not occur on the opening folio of the movement (f. 15v, music paper C), where 'Anna' appears without alteration. Additional details of the revision process are revealed through a closer analysis of the movement's text.

The first section of 'From this happy day' finishes on the bottom half of f. 13r, with a substantial section left blank and an incomplete bar with custodes showing the following notes (Figure 5, where the scoring is 


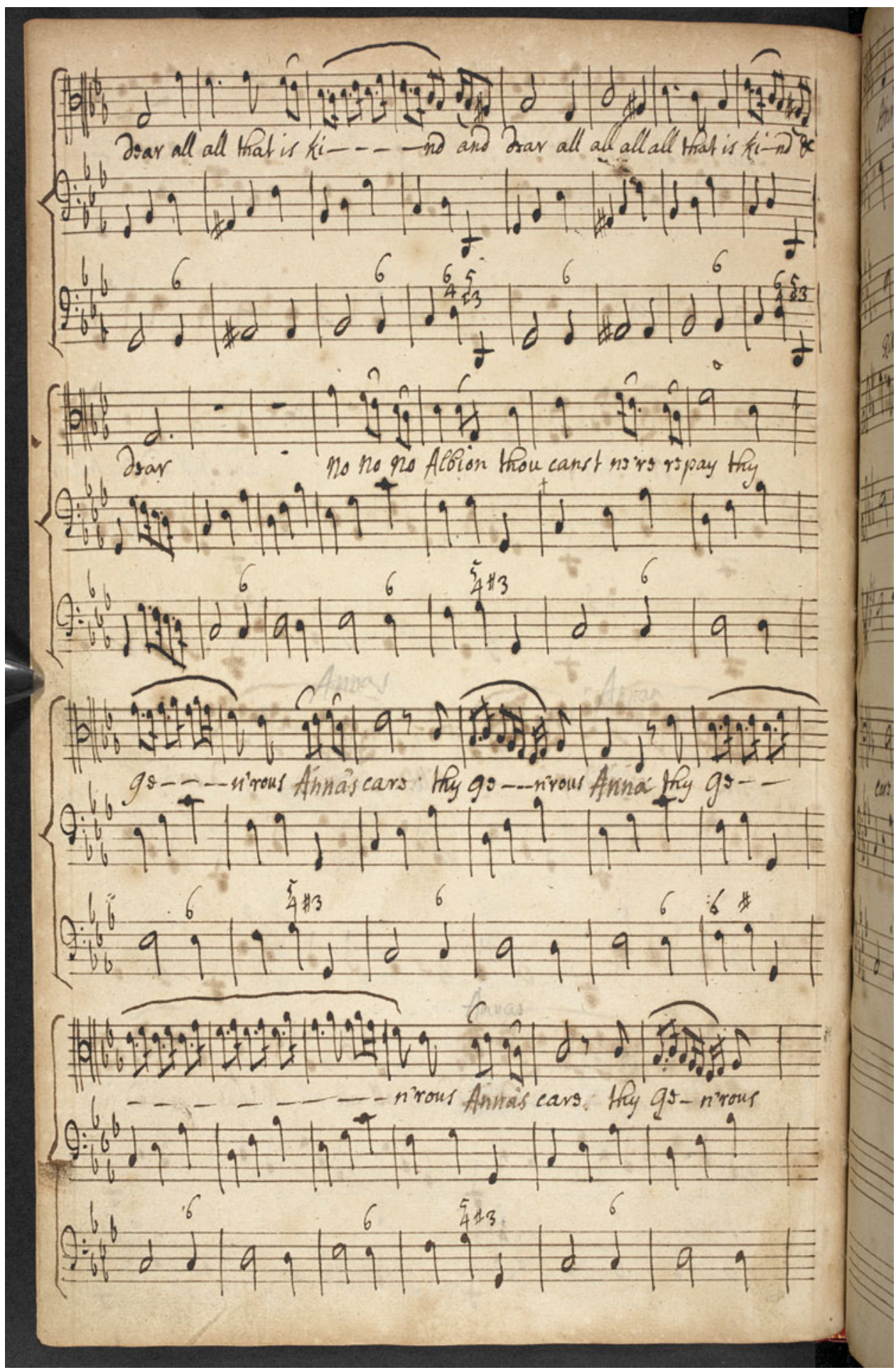

Figure 4 (Colour online) Eccles, Inspire Us Genius of the Day, reprise of 'No, Albion, thou can'st ne'er repay' with emendations visible to the word 'Anna'. 'Anna' is also visible in pencil above staves 7 and 10. GB-Lbl, Add. 31456, f. 16v. Used by permission 


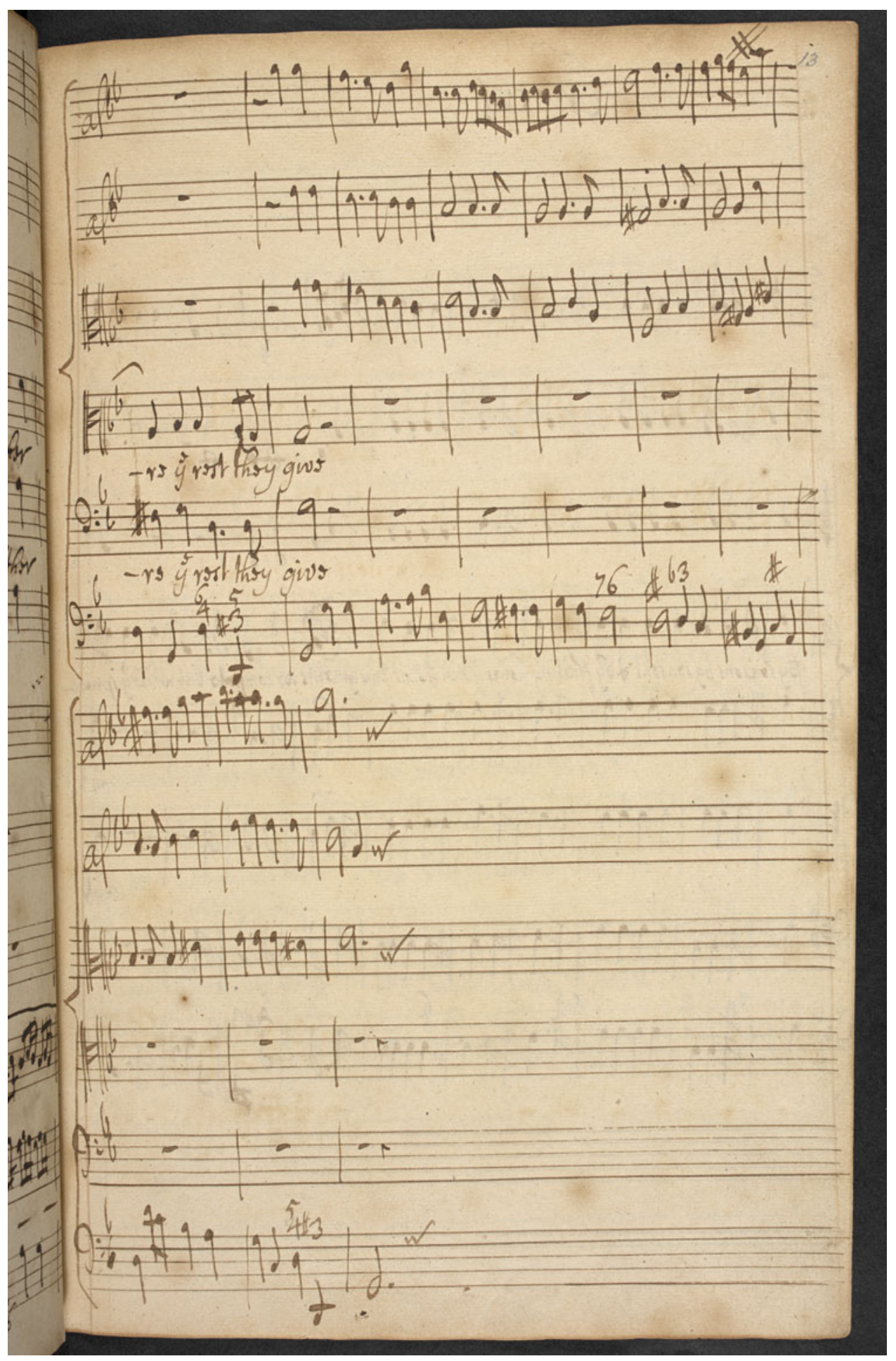

Figure 5 (Colour online) Eccles, Inspire Us Genius of the Day, end of first section of 'From this happy day', showing incomplete bar with custodes. GB-Lbl, Add. 31456, f. 13r. Used by permission 
for two violins, tenor violin, tenor and bass voices and continuo). On f. 13v a section for chorus begins and continues to f. 15r. The text of this new section reads:

By seasons and by fleeting hours

The sun's enjoyments we compute

But while the spring can boast but leaves and flow'rs

Her virtue still new Blessings pours

That ever acts we ever taste the fruit.

This is a decidedly more feminine text than has been encountered earlier in the ode. Extolling King William's virtue as being greater than the leaves and flowers of spring does not figure his previous birthday odes, and indeed the word 'virtue' only appears in odes from this period when the text refers to a female. No alterations have been made to the text of this section, though it uses the feminine possessive 'her', indicating that fols 13-15 were newly added following William's death because the original textual content was deemed inappropriate for a female monarch. We have no way of knowing whether the music for this chorus (presumably on leaves of music paper A) was the same as that originally written for William III, or whether the music was composed anew when Eccles was furnished with new text by Motteux. In any case, the fact that Eccles deemed it necessary to insert new pages suggests that the original text was very different from the revision. It also explains why amendments were made to the reprise of 'No, Albion, thou can'st ne'er repay' but not to the first page, which had to be rewritten on f. 15v, the reverse of a newly added folio of music paper C. Folios 16-17, as would be expected, are leaves of music paper A. The distribution of paper types and the substitution of the name 'Anna' throughout the rest of the movement verify that movement 5 ('No Albion thou can'st ne'er repay') was written before the closing section (fols 13v-15r) of movement 4 ('From this happy day').

Movement 6, 'Firm as a rock' (bottom of fols $18 \mathrm{r}-21 \mathrm{v}$ ), also reveals some interesting clues as to Eccles's method of reworking the ode. Folio $17 \mathrm{r}$ (music paper A) bears the final sung line of 'No Albion thou can'st ne'er repay' (with the amendment 'Anna') and the movement's concluding ritornello, which carries on to f. $17 \mathrm{v}$ (also music paper A) and to the top of f. $18 \mathrm{r}$ (music paper C). The paper type changes in $\mathrm{f} .18$ because 'Firm as a rock' begins here. No textual amendments were made to this movement, which contains words lending themselves exclusively to a female ruler. This, in combination with the presence of music papers B and C, reveals that 'Firm as a rock' was newly added following William's death. It might be argued that a sixth movement had not even been begun at the time of the king's demise. However, had there been no 'original' sixth movement, there would have been empty staves at the bottom of an original f. $18 \mathrm{r}$ (with music paper other music originally followed the concluding ritornello of 'No Albion thou can'st ne'er repay'.

At this point it is easy to see that recovery of the entire original text for William III is impossible. It is also evident that much more of the ode had been composed by the time of the king's death than has hitherto been thought. In fact, close examination of the seventh movement, 'Great Queen go on' (fols 22-29), reveals that the entire ode had probably been completed by the time of William's demise. The bulk of this final movement is written on music paper B, on which there are no textual amendments. Because the queen is mentioned repeatedly from the opening, there can be no doubt that much of 'Great Queen go on' was written afresh and inserted into the work. However, the final three folios of the movement (fols 27-29) revert to music paper A. Most significantly, as can be seen in Figure 6, a textual amendment was made to change the word 'he' to 'is' on fols $27 \mathrm{r}-27 \mathrm{v}$. Thus the end of the ode had been completed by the time of William's death, with a text originally reading 


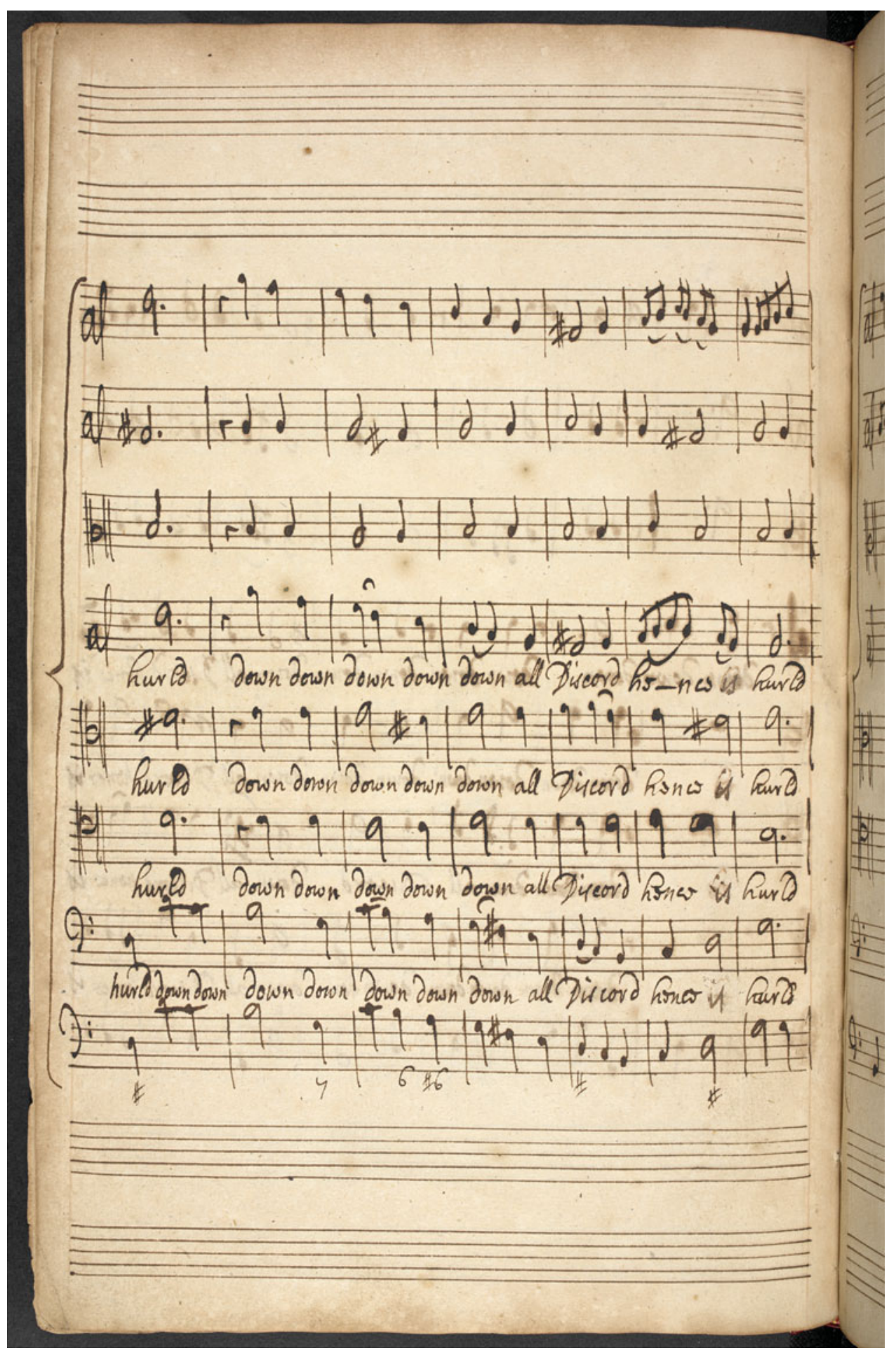

Figure 6 (Colour online) Music Paper A, showing textual emendation to the word 'is' on staves 6-9. GB-Lbl, Add. 31456, f. $27 \mathrm{v}$. Used by permission 
A terminal flourish at the closing bar on f. $29 \mathrm{v}$ confirms that the ode existed as a complete work for William before it was reworked for Anne.

It seems most unlikely that this birthday ode, if intended for 1702, would have been completed (in its earliest form) before the king's death in March 1702, given that his birthday was not until November. It is therefore far more likely that Inspire Us Genius of the Day was originally intended for performance at the king's birthday celebration in November 1701. But, as things turned out, the king was not in London for his birthday in $1701 .{ }^{25}$ The celebration of his return from Holland and of his birthday (in his absence) was reported in both The London Gazette and The Post Man:

Whitehall, Nov. 5

The King came yesterday from Margate to Sittingborne... and came this evening to HamptonCourt. Yesterday was celebrated His Majesty's Birth-day; and the Publick Joy on this Occasion being very much encreased by the News of His Majesty's good Health, and safe Arrival, the same was expressed in an extraordinary manner by Ringing of Bells, Bonfires, and Illuminations, in the Cities of London and Westminster. ${ }^{26}$

Inspire Us Genius of the Day, having already been composed in its entirety (and possibly even rehearsed), must have been shelved for 1701. With no birthday celebration in 1702, the ode remained unperformed until it was reworked for the first celebration of Queen Anne's birthday, on 6 February 1703.

It must have been Eccles, as Master of the Musick, who decided to alter the ode and advised Motteux what textual changes were needed. This collaboration allowed them to save most of a fully composed ode, sparing Eccles the onerous task of writing new music. As we shall see, their choices of textual emendations raise issues of creative authority on the parts of poet and composer while offering insight into the mechanics of monarchical image projection and its relationship to the fashioning of authorial identity.

\section{REGIME, REVISION AND CREATIVE AUTHORIAL IDENTITY}

In revising Inspire Us Genius of the Day, Eccles and Motteux faced the task not only of rewriting an ode, but also of rewriting a regent. With the change in monarch came a change in regime, the tone of which was easily identifiable in the new queen's first address to parliament, in the choices of psalms, anthems and readings at her coronation, and even in her personal appearance. ${ }^{27}$ Poet and composer were here salvaging an ode originally written for a male monarch of foreign birth who was lauded as a military hero, now applying it to a female ruler born and raised in England whose gender prevented her from being anything other than pious, virtuous and devout. ${ }^{28}$ Their decisions were made under the dual pressures of presenting their individual selves publicly as competent in their respective arts while simultaneously concealing the fact that the work had originally been intended for William III. The changes made to Inspire Us Genius under these pressures help illuminate the complexity of creative ownership in such a collaborative endeavour. Moreover, the version of the poetic text published separately from the music ('Version C' in Table 4) provides a window into the differing public images projected by William III and Queen Anne and highlights the distinctions between an ode as a performance, as a printed song and as a printed poem divorced from its music. As we shall see, this printed poem allows us to draw conclusions that would not have been possible on the basis of the autograph manuscript alone.

25 The Post Man, 31 December1700-2 January 1701. Quoted in McGuinness, English Court Odes, 24.

26 The London Gazette, 3-6 November 1701; The Post Man, 4-6 November 1701.

27 See Winn, Queen Anne, chapter 6. On her first address to parliament, Anne's costume was modelled on a portrait of Queen Elizabeth. Edward Gregg, Queen Anne (London: Routledge, 1984), 152, and Winston S. Churchill, Marlborough: His Life and Times, volume 1 (London: Harrap, 1947), 499.

28 On this point see Estelle Murphy, “Sing Great Anna's Matchless Name”: Images of Queen Anne in the Court Ode', in Queen Anne and the Arts, ed. Cedric D. Reverand II (New York: Bucknell University Press, 2014). 
The first textual alteration to the manuscript on f. gr ('William's birth and Europe's joys' to 'Anna's birth and Britain's joys') is surely not insignificant. Although heralded as the saviour of the Protestant faith, William III was still a foreigner whose public image in Britain, especially after Queen Mary's death, had depended on his status as a European hero. In contrast, Queen Anne emphasized her Englishness or 'Britishness' from the beginning of her reign. There are many examples of her 'English' self-fashioning, such as the reference to Elizabeth I in her first address to Parliament on 11 March 1702, when the new queen declared 'I know my heart to be entirely English'. ${ }^{29}$ Such references succeeded in portraying Anne as having descended from a long line of English monarchs, in stark contrast to her predecessor, whose documented reluctance even to speak the English language resulted in a closed and alienated court in the latter part of his reign. ${ }^{30}$ Anne also adopted Elizabeth's motto, Semper eadem, as her own. This choice is significant for more than her self-fashioning as Elizabeth, however, as its meaning - literally 'Ever the same' - suggested the image of the new queen rising, Phoenix-like, from the ashes of her predecessor. It also allowed an escape from an alternative view of her: as a queen indebted to the Glorious Revolution and her betrayal of her father, James II, in favour of William and Mary. Anne's imitation of Elizabeth and pride in her Englishness were certainly not lost on her subjects.

The changes made on f. 11r demonstrate a similar awareness of King William's status as a hero and the incongruity of such a depiction for the new monarch. The phrase 'Our Hero greater... yet' was amended to 'Her reign yields/gives greater Blessings yet', though it does not match the original syllabic setting. As we have seen, Eccles apparently first changed the second syllable of 'Hero' to 'yields' and later to 'gives', but forgot to alter 'yields' to 'gives' on staff 10 . Unfortunately, the words that originally followed 'Our Hero' in the earlier version of the ode are irretrievable. Yet it is clear that the image of the king as a war hero, so common in his earlier birthday odes, was continued in Inspire Us Genius and that the changes both suited Queen Anne's gender and discouraged recognition of the ode as a reworking. They also allowed Eccles to avoid substantial alterations to the music he had written, and it is therefore tempting to suppose that it was he who exercised creative authority over the reworking, with Motteux simply furnishing words suitable for the new monarch and the pre-existing music. This reverses the usual practice of the poet providing the composer with a text to be set to music (as would presumably have been the case when the ode was originally written for William III).$^{31}$ However, the procedure of fitting words to pre-existing music was extremely common, as in the setting of broadside poetry 'to the tune of a well-known ballad melody. It can also be observed in the long-standing practice of fitting contrafactum English texts to Latin motets. ${ }^{32}$ As Rebecca Herissone has shown, a similar practice is observable in the serial recomposition of Carminum praeses. This Oxford Act song shows evidence of creative input from at least two and probably three composers and also evidence of recycling for different events on at least two occasions over a period of twenty-five years. ${ }^{33}$ This is in contrast to assumptions that occasional pieces such as this were performed only once. Carminum praeses has an obvious similarity to Inspire Us Genius, which was reused in a new context with much recycled music.

29 Queen Anne's self-fashioning in relation to Elizabeth I is discussed in detail in Murphy, 'Sing Great Anna's Matchless Name', and in Winn, Queen Anne, especially chapter 6.

30 Stephen B. Baxter, William III (London: Longmans, 1966), 248.

31 There appear to have been occasions when the text of a work was published before being set to music, or, in the case of the 1693 playbook for Purcell's The Fairy Queen, before being altered to reflect a revised setting. See Herissone, Musical Creativity, $135-138$.

32 For a detailed discussion of Henry Aldrich's engagement in such practices see Robert Shay, "Naturalizing” Palestrina and Carissimi in Late Seventeenth-Century Oxford: Henry Aldrich and His Recompositions', Music \& Letters 77/3 (1996), 368-400.

33 Rebecca Herissone, “To Entitle Himself to ye Composition”: Investigating Concepts of Authorship and Originality in Seventeenth-Century English Ceremonial Music', unpublished paper presented at the Sixteenth Annual Conference of the Society for Seventeenth-Century Music, University of Southern California, 2008. My thanks to Rebecca Herissone for sharing her paper with me. 
The third movement of the ode, 'Blest day' (fols $7 \mathrm{r}-7 \mathrm{v}$; printed version in Figure 2), includes an equally interesting case of alteration. No textual changes were made to this movement for solo tenor voice and continuo, and as a result its message lies less comfortably than the rest of the work, as can be seen from the following lines:

Blest day arise in state

And roll Along the spheres,

As glorious, fam'd, and great

As moves the morn

From whose return

bright Phoebus dates his years.

This verse, with its invocation of Phoebus (either the god Apollo or the sun), is clearly a male reference suitable for King William's birthday. As Andrew Pinnock has argued, Phoebus was a particularly important image for Charles II. ${ }^{34}$ It is likely that the invocation of Phoebus in Inspire Us Genius was an effort to legitimize King William's rule by association with a familiar image. While comparisons of the monarch to the sun and mythological gods are certainly not uncommon in poetry for both kings and queens, it is most unusual for a male god to be invoked in an ode for a female monarch. The retention of this distinctly male-oriented verse for Queen Anne is justified in the printed form of the poem (Version C) by the following lines, absent from the musical setting:

The Day that Anna's Race begun

These lines effectively sidestep the original comparison of the monarch with Phoebus by saying that Queen Anne's birthday vies with that of the sun god. Moreover, the choice to alter the printed poem but to retain the original text unaltered in the musical setting demonstrates that the printed medium held more risk of betraying the ode's status as a reworking. It is worth noting, too, that when 'Blest day' appeared with the music in Eccles's printed editions of 1703 and 1704 it was presented without any textual changes under the title 'A Song Sung by Mr Elford on Her Majestys Birth Day' (see Figure 2). This suggests that the reference to Phoebus was expected to be overlooked not only by the audience present at the ode's performance but also by those who purchased the printed ode songs simply on account of the words being set.

Though the emendations to this ode could be seen as merely practical - certain phrases were very obviously inappropriate for a female monarch - the addition of verses to the printed version of the text raises issues of authorial intention and self-fashioning. Published items such as these are essentially a performance manifest in print, and the changes made for printed texts reveal authors' intentions altering with the medium. This is evident in a verse inserted before the final chorus in the printed version of Inspire Us Genius of the Day:

Brave Race of Troy, still wisely dare!

While your Pallas is your Care,

The Genius of Defence is here.

Your Altars Piety secures,

And Wisdom ev'ry Good insures:

Thus guarded best,

And ever blest,

34 Andrew Pinnock, “'Deus ex machina”: A Royal Witness to the Court Origin of Purcell's Dido and Aeneas', Early Music 40/2 (2012), 265-278, and 'Which Genial Day? More on the Court Origin of Purcell's Dido and Aeneas, With a Shortlist of Dates for Its Possible Performance Before Charles II', Early Music 43/2 (2015), 199-212. 
The verse fits well with this section of the ode, especially given the reference to Pallas in the preceding movement ('Our Pallas thus appears in Arms'). It is uncertain exactly when Motteux decided to include this verse, which does not appear in Version B as set to music by Eccles. It is possible that, for the reworking of the ode for Queen Anne, Motteux provided Eccles with the revised text as it later appeared in print. If this was the case, then authority over the presentation of the work for performance, through setting the text to music, lay with Eccles. Alternatively, Motteux might have revised the text for publication, inserting the verse after Eccles had set the rest of the ode, so as to improve its presentation and reception as a stand-alone poem. However, given other discrepancies between Versions B and C, highlighted in boldface in Table 4, it is likely that Motteux did undertake some revision of the poem for publication. These alterations are small but significant, for many of the revised lines are more alliterative, articulate and rhythmical for the reader than those in Version B. While this does not change the fact that Eccles had authority over the performance version of the ode, it does show that two different instances of authorial self-fashioning are at work here. Eccles, in setting the text, must have been concerned with writing music that would appeal to the theatre-going public (as is reflected in the style of the solo songs). In addition, there can be little doubt that the composer had the ode's future printed form in mind while reworking it. None of Motteux's small changes appear in the printed versions of Eccles's songs. It seems clear, therefore, that in both versions of the ode, Eccles presents himself as a composer conscious of the musical rather than poetic value of his work. He probably divided Motteux's original poem into movements, altered or rearranged words and lines, and possibly omitted verses as he saw fit to serve the musical setting.

Motteux's printed text shows a second authority, revealing that the poet also understood the subservience of poetry to music and tried to improve the ode text for publication. In doing so, he was attempting to be viewed as a poet of merit. He knew that the ode poem as set to music - with division into movements, word repetition and alterations to word order - obscured the poem as it would be read or declaimed as poetry. Despite the existence of Eccles's printed songs and the public's knowledge of the ode in performance, Motteux substantially altered his poem in order to fashion and protect his reputation as a poet. Had his printed poem included a preface, its sentiments might have echoed those of Thomas D'Urfey in his New Poems (1690):

The Odes and Songs that I have here publish'd, have I thank Fortune, as well as those formerly printed, generally pleas'd the Town and though some may appear a little rough and unpolish'd in the Reading, the amends is made when they are Sung, for I have still taken care to put some Fancy and Thought in them, and the Judicious are sinsible that 'tis no easie matter, nor is it every one's Talent to Confine Sense and smooth Verse into Notes, the quality of performing it well, being as particular as difficult. ${ }^{35}$

Even though the 'Odes and Songs' published by D'Urfey were well received when they were performed before the 'Town', he is conscious of the fact that this reception may not transfer to the 'rough and unpolish'd' manner of the very same works when presented in isolation from the music. This may be precisely what Motteux was attempting to avoid by revising the poem of Inspire Us Genius of the Day for publication. Eccles's publication of songs from the ode did not, of course, take such things into consideration. In this respect, it is significant that only he is named in the print, not Motteux, representing the composer's rather than the poet's authorial identity. Conversely, both poet and composer are named in the published poem, with Eccles's name appearing first and in a bigger font size than Motteux's. The primary function of this birthday ode - to be performed as a musical work - is underlined when the composer is prioritized in this way, as is the idea that the text is subservient to the music. Taken together, the two publications reveal how differing presentations of authorial identity can affect perceptions of a work.

35 Thomas D'Urfey, New Poems, Consisting of Satyrs, Elegies, and Odes: Together with a Collection of the Newest Court Songs, Set to Musick by the Best Masters of the Age (London: Bullard, 1690). GB-Ob, Harding C 1197 (1). 
We have seen that Inspire Us Genius of the Day has a more complex history of revision and reworking than previously recognized. Analysis of paper types, stave rulings and textual emendations uncovers much about the process of transforming an ode written for King William III into one suitable for Queen Anne, a process informed not only by differences in gender, but also by the monarchs' efforts to mould their public image. Meanwhile, two interrelated cases of authorial self-fashioning are revealed through textual discrepancies between the printed poem and songs. Inspire Us Genius of the Day thus emerges as a uniquely evolving 441 cultural artefact of the late Stuart period. 